\title{
Early Experiences of Women and Planning Initiatives 1980-1990
}

\section{Introduction}

The introduction of policies for women in the planning process and consideration of women as professional planners was given a major lift in the early 1980s. Through the development of US literature and the establishment of the GLC Women's Committee in 1981, there was a new focus and urgency to the discussion of these issues and the beginnings of an approach to gender mainstreaming in planning that emerged in the 1990s and then became submerged again in the 2000s. This paper sets out the recollections of two women planners working in local government and the community sector who were active in these issues in the 1980s and 1990s and considers the reception of this turn to recognise women in planning and their respective experiences of being part of these processes The paper sets some of the context for these experiences then goes on to narrate the two sets of individual experiences. The last part of the paper reflects on what has happened since and whether this legacy has any continuing impact on current practices.

The debate about the relationships between women and the environment had been emerging in Australia and the United States in the 1970s. In Australia, a report written about Australian cities provoked the initiation of a discussion about women in planning and planning for women (Ferrier $1976,1977)$. In the United States in the 1970s this was primarily focussed on the design of interior spaces within housing but also the wider issues of access and the external environment including personal safety (Hayden and Wright 1976; Holcomb 1978)..

The developed into a literature on women and architecture, geography and the city that started to emerge at the beginning of the 1980s, contributing to a platform of writing on women in the built environment. Women and the American City (ed Stimpson et al 1980) provided an initial and comprehensive scoping of the issues that were later to be developed in more detail. In this, Wolshuk (1980) reviewed a special edition of the International Journal of Urban and Regional Research (1978 vol 2 no 3) that had been produced by a caucus of the British Sociological Association and included articles on home and community (Newby 1978), child care (David 1978) and women's aid (Rose 1978). This had been a significant precursor to Stimpson et al's volume and, as Wolshuk states, the collection was both 'provocative and useful' (1978:271). There was also a wider literature review of what was already available (Griffen 1980) at the time that Stimson et al were considering the contributions to their book.

Women and the American City included significant contributions to the development of thinking about the issue of women and planning in a seminal way. This book took as its focus the way in which women 
used the city including parks (Markson and Hess 1980a), how women travelled (Lopata 1980) and the intersection between mobility and women's life patterns (Markusen 1980). It considered the needs of specific groups such as older women (Cranz 1980), those with childcare responsibilities (Michelson 1980) and women engaged in urban management (Leavitt 1980; Burns 1980). It also considered the masculinity of the city and the feminisation of the suburbs (Saegert 1980).

This was followed by Geography and Gender An introduction to feminist geography which was authored by the Women and Geography Study Group of the Institute of British Geographers (IBG) (1984) following a conference on the issues. It has a foreword by Doreen Massey who described its work as being 'instrumental in pushing both critiques further and in new directions' (1984: 11). The book is structured in three parts - starting with a discussion about the theory and practices of feminist geography, followed by a second part that considered women within the urban structure, in relation to employment, access to facilities and development. The last section considered the role of feminist geography in teaching and research. Some of this work was developed further in a special edition of Built Environment in 1984. In her editorial to this special issue, Bowlby (1984) undertakes a brief review of the literature and she emphasises the collective nature of the efforts to develop the field. She mentions three specific initiatives. The first is the Women in Planning group, founded in 1982 and included later as part of the experience described in this article. The second is the Matrix group of architects and planners that had published a collection of articles in Making space: women in the manmade environment (Matrix Book Group, 1984) and the third was the IBG group of which Bowlby had a leading role. While Bowlby describes the papers in this special edition of Built Environment as a small sample of the work that was being undertaken, it represented the range of themes in Women in the American City through some further examples from the US including on the role of women in the suburbs (Wagner 1984) and women in city redevelopment (Holcomb 1984). From the UK, Ravetz (1984) wrote about women's interior space as expressed through the home and Boys (1984) about whether there is a feminist analysis of architecture. There were also articles about the British experience in relation to women and travel (Pickup 1984) and employment (Price 1984; Lewis and Foord 1984). Bowlby (1990) also wrote about the ways in which gendered work patterns and incomes are related to travel time which has been fundamental in the understanding of the rise of inner-city gentrification.

\section{Context within London}

The context for the emergence of discussions and subsequent policies for women within planning that started in the UK in the early 1980s was part of this. It was based on a heightened awareness of women's equalities through the passage of the Sex Discrimination Act 1975 and Equal Pay Regulations 
in 1983 (Lacey 1987). Neither of these legal changes created the longer-term shifts that were anticipated and were followed by other legislation. Nevertheless were instrumental in allowing these issues onto the agenda.

In the late 1970s, in London, the emergence of more left-wing politics within the London Labour Party was manifesting itself both in the London Boroughs and in the selection of candidates for election to the Greater London Council, then the principle strategic local authority in London (Boddy and Fudge 1984). After the 1981 GLC elections, the new Leader of the Council, Ken Livingstone, and his new Councillors set about restructuring the Council to change its focus to issues that they considered important for Londoners (Forrester et al 1985; Hebbert, 1995). The GLC was abolished by the Thatcher Government in 1986 along with other strategic metropolitan councils. (O'Leary 1987; King, 1989).

The new GLC structures that were introduced under the Livingstone leadership included the establishment of a Women's Committee in 1981, chaired by Valerie Wise. The Women's Committee, over its time in office, published a range of reports including special surveys on transport (Wise 1985) and a regular bulletin. The Committee produced 'The London Women's Handbook' (GLC 1986) that included a range of chapters on different issues that the Committee had addressed. The chapter on planning stated from the start the impact of planning and built environment on women's lives. Fulfilling its handbook role, it set out what planning is for and the organisation of planning functions within each council.

The Women's Committee associated its work the review of the Greater London Development Plan (GLDP) into the London Plan (1984), when the Committee had been concerned with a range of issues including equal opportunities, housing, town centres, employment and ensuring a safe environment. To this was added the need to consult women on planning issues as a core necessity and resulted in the inclusion of a chapter on women in the draft revised GLDP. Through this Handbook and the Programme for Action, the Women's Committee set out how London Boroughs and in the GLC's own Planning and Development Department should address planning issues for women. The Women's Committee also commissioned specific work on issues that are related to planning including a shopping survey which included access to the kinds of services and facilities that women need in the retail environment. All of this was regarded as positive 'popular' planning (Palmer 1986; Brindley et al 2005). The Handbook included four pages of organisations that could support women in the planning process including community technical aid, national organizations and local centres. Finally, the Handbook pointed to a range of references where it was possible for find out more about the ways in 
which women's issues could be addressed within the planning process including Stimpson et al (1981), Hayden (1982) and IBG (1984).

These concerns gradually moved up the agenda and led to more concrete actions and initiatives. The Draft Alterations to Greater London Development Plan (GLDP) (1984) included a section "Women in London" and 'Changing Places - Positive Action for Women' (GLC 1985). The major points discussed in the GLDP as well as the "Changing Places" included how post war planning policies had failed to take account of social and demographic changes, especially in relation to the rise in single parent families and changes in women's employment patterns. They concluded that women are excluded from planning's decision-making processes while the majority of planners at senior levels are male. Practices employed by the planning authorities also exclude women from consultation processes. Therefore, women have little control over the environment that they live in.

The review of the GLDP (1969) from 1980 onwards and Changing Places (GLC 1986) included a range of planning issues. However, the underlying concepts in all those areas clearly indicate that women, mostly due to domestic responsibilities, are tied to their home and locality more than men (Bowlby 1990). The emphasis in the short term was on accessibility and safety in the built environment as well as provision of local facilities for shopping, leisure, and employment. However, in the long run, they stated that commitment should be given to widen the opportunities for women to be involved fully with public life. Factors that tie women involuntarily to home and locality, to caring responsibilities and to low paid jobs should be addressed by planners.

The revised GLDP, as the London Plan, did not come into force and never superseded the 1976 version. When the GLC was abolished, the strategic planning function and leadership was removed to be replaced by the Government through the Department of the Environment's Regional Office for London and by the London Planning Advisory Body (LPAC) which comprised of one representative from each London Borough but had no powers (Travers 1990). The Government published strategic guidance on planning for London in 1989, but the role of women had been lost in a more traditional approach to planning. The issues that had been addressed by the Women's Committee were transferred to the newly established London Strategic Policy Unit described by Travers as a 'GLC in exile' ( $p$ 114) but this was closed down in 1987, just a year and a half after the GLC was abolished, as it did not have enough funding to continue.

In a later interview, Valerie Wise reflected on her experience as the chair of the Women's Committee including the criticism that their work received from the press, including the Daily Mail. Overall, her memories were positive: 
'Her days at the GLC were the highlight of her political career - so far. "It was a wonderful time, the most fantastic experience. I think the women's committee was brave and ahead of its time. We felt that child care was at the heart of a lot of problems to do with women. Everything we were advocating then is now mainstream thinking. There are all these focus groups now but we did that in 1984 . We went out and listened to women's views and incorporated them into our policy. The difference was we had money. Women's organisations still don't have money. What we said then is absolutely relevant today. It's no longer thought of as radical, but the norm." ' (Weale 1999).

The establishment of the GLC's Women's Committee was followed in some form by forty other local authorities which explicitly addressed the needs of women in their areas although few had any focus on planning and the environment (Edwards 1988; Halford 1988). While these arrangements varied in their type and role, they were largely dependent on political patronage for their institutional formation and there was no legal basis for their decisions to be endorsed. While local authorities were obliged to observe the Sex Discrimination Act 1975, much of the opportunity for participation in the workplace and as a councillor depended on access to and costs of childcare and transport. These considerations were very important and remain the case.

In London, a number of boroughs set up women's committees or employed women's issues officers. The Women's Design Service (WDS) that was established in 1987 by a group of women architects and undertook work partly funded by the GLC until 2012 (Beebeejaun 2017). During its active period, the WDS published a range of guidance and broadsheets. The RTPI also produced an advice note on Planning for Women in 1996.

One group who committed time and effort to gender issues in 1990s was the London Women and Planning Forum, earlier referred to by Bowlby $1(984)$ as the Women in Planning group) , a network for women planners and planning students who were interested in discussing a wide range of planning issues from a gender perspective. The group met about four times each year to discuss women and planning issues, identify good practice and provide support and advice to women planners. The meetings often had challenging and thought-provoking presentations followed by discussions and attracted a wide audience with people working in local authorities and academia, as well as other sectors and community organisations concerned with planning and equality issues. The support from the Women's Design Service (WDS) played a crucial role in keeping the Forum going (Beebeejaun 2017). In fact, the Forum probably would not have survived so long if it had not come under the WDS umbrella. Meeting notes were published as Broadsheets by the WDS. The topics included designing out crime, town centres, planning education, housing and women's position in planning departments. 
Image 1 - Examples of London Women and Planning Forum Broadsheets

\section{Writing about our experience}

Within this London context, the approach taken in this article is to use episodes in the authors' careers to record and illustrate events in the development of the role of women in planning in the decade between the early 1980s and 1990s. While life writing about personal experiences always has an influence on the selection of written content and perspective, these personal realities can also have some objective truth (Jenson 2009:310). Life writing is a wide field and includes a range content, it includes lived experience and testimony. There has also been a growing literature of women writing about recovering and contributing to different memories that help to (re) construct traditions and shared cultures (Huff 2003).

In terms of our careers, to contextualise the later content of this article, we should say more about ourselves. Janice Morphet started a career in planning after a first degree in sociology in 1969. During the decade that followed, Janice worked in three London Boroughs - Enfield, Islington and Tower Hamlets and had also had short stints in a County Council and the Department of the Environment. Janice qualified as a chartered town planner in 1974 after taking a part time course at the Polytechnic of central London (now the University of Westminster). By 1982, Janice had one daughter and was working in the LB Tower Hamlets on the delivery of the Urban Programme. Since the mid-1970s, Janice had also been active in the work of the RTPI as London Convenor, member of the RTPI Council and then a member of the Education Board. By 1981 she was chair of the part time education board.

Sule Takmaz Nisancioglu started working on a project titled "greening the city" in the Planning Policy and Projects service of London Borough of Haringey in 1987 after completing her PhD in Ecology in University of Newcastle upon Tyne. Her newly found love of planning led to her staying in Haringey and completing a part-time masters course in town planning in Polytechnic of Central London while working. Like Janice, her local authority supported the study with fee payments and flexible working. Sule worked on various projects ranging from Urban Programme for environmental improvements to design guides for safe environments before becoming a Women's Issues Officer in 1988 - a newly created post to address gender inequalities in planning policy and practice. She was an active member of the London Women and Planning Forum. During following decades, apart from Haringey she worked in Barnet, Camden and Enfield councils in areas of local plan making, sustainability, planning for climate change, regeneration projects and eventually as head of service for local plans, heritage, transportation and infrastructure planning. She is a member of RTPI. Sule is currently taking a break 
from full time work and focussing on making short documentaries which explore the links between cities and people's lives. She has two sons.

We have tried here to recollect and recount about direct experience of being involved in Women and Planning issues in the 1980s. We could have chosen to write about the ways in which our careers and home lives interacted and how we managed these (Freidman and Greenhaus 2000), which would also be a contribution to the collective memory of women and planning. Instead we have chosen to write about our very specific experiences on the development of the recognition of women and planning issues during this period. Such recollections are subjective and flawed but they are also helpful to record both events and their context. They represent a reflected set of emotions and experience that is a memory of personal truth. In the case of these authors, there are some contemporaneous fragments that have survived that have served to jog memories by reflecting encounters and moments. Neither author has written about these events before as personal memories, so this testimony of the past is fresh to the page.

\section{Managing a planning career}

While much of the literature discussed the role of women in the urban environment and their interactions with it, there was less written about women within a professional planning context either employed within a local authority or as a consultant, the two main types of employment for women planners in the 1980s. There were also some significant women in the academy including Heather Kerswell (Kingston), Patsy Healey (Kingston and Oxford Brookes), Glen McDougal (Oxford Brookes) and Jane Darke (Sheffield).

For the majority of professional women until the 1970s, they typically suspended their careers if they had children and although work sharing was possible in planning and the civil service, it was frequently left to the job sharers to find suitable sharing partners and make their own arrangements for how this would work in practice. In planning sharing a case load but being responsible for different cases was possible as was taking different topic responsibilities within a planning policy team. However, it remained a rare experience. These issues were discussed at a one-day conference on Women and the Planned Environment in 1982 held at the Polytechnic of Central London (now the University of Westminster). This day was a mixture of sessions and networking and there were many young children present. 
The development of the role of women within the planning profession and the community engaged in planning issues was a key driver of some of the debate. The planning profession was male dominated although there had been a women President of the Royal Town Planning Institute (RTPI), Sylvia Law in 1974. However, it was 20 years before the second woman President was elected. Within planning practice, most planners were employed in local authorities and the public sector. They were increasing in number as junior planners but there were few at the top of the profession. A notable exception was Audrey Lees who was City Planning Officer in Liverpool and then moved to take a similar role in London (Greed 2003). In the 1970s, the Radical Institute Group 1975-1977 had sought to reform and refocus the RTPI from within, to address issues such as equality and redistribution but this group was incorporated and mainstreamed (Hague 2017). The RTPI became more aware of these issues in the early 1980s and took on the task of considering the issues and how it should support more gender equality particularly through monitoring entry to planning courses and in the profile of the profession (Greed 1996). However, other more proactive approaches such as mentoring and coaching were not offered in planning although they were offered through the Local Government Training Board from the late 1980s onwards. The RTPI also had a role in the curriculum content of recognised planning courses and again this issue was included within the review of planning education in the early 1980s as one issue amongst others (Brown et al 2003).

\section{What was our experience?}

Both authors were participants in the events and discussions that took place in this decade. Drawing on contemporaneous material and our experiences, there were a number of key issues and challenges and concerns that, as female planners, we were discussing in 1980s and 1990s. These were increasingly represented in a range of studies and reports (GLC Women's Committee Reports, RTPI Women and Planning Advice Note (1996), London Women and Planning Forum Broadsheets, Greed, 2003; Roberts and Greed, 2014)

These issues included:

$\underline{\text { How women use cities and land use differently from men }}$

Women use cities and land uses differently from men and many have quite different life-styles and daily activity patterns from their male counterparts. Far from being gender neutral in design, modern cities appear to be designed and planned primarily to facilitate the activity patterns and needs of the male population (Markusen, 1980; IBG. 1984; Bagguley et al 1990). 


\section{Transportation policy}

Transportation policy has conventionally been developed within modern town planning practice to accommodate the needs of the traditional 'breadwinner' in his uninterrupted journey to work. Women are more likely to work part time, to work outside the home in more local forms of employment, and to combine formal employment with homemaking and childcare duties. This is likely to result in more off peak travel patterns, which will also be characterised by being more likely to be tangential, between local areas, rather than radial. Women has less access to cars and experience the microenvironment, streets and shopping areas and public transport differently to man. Public transport has, likewise, been geared to meeting the needs of peak time, rush hour travel, whilst radial road building programmes, and the location of car parking provision have also enforced this model.

Also such journeys are more likely to be broken several times between home, child care, school, work, GP clinic and managing the public interfaces for households. The problems are compounded by the fact women have less access to the use of a car during the daytime, and thus are dependent on public transport. Women has less access to cars and experience the microenvironment, streets and shopping areas and public transport differently to man. Public transport has, likewise, been geared to meeting the needs of peak time, rush hour travel, whilst radial road building programmes, and the location of car parking provision have also enforced this model (Lopata 1980)

\section{$\underline{\text { Care }}$}

In many households' women still have the main responsibility for looking after children or elderly relatives (Yogev 1981; Floge 1985).

\section{Shopping}

Women frequently retain the responsibility for food shopping and preparation. There was less eating out in the 1980s, wither in cafes at lunchtime or in the evening or at weekends. Many people including school children had packed sandwich lunches which also had to be prepared. Women's mobility in and around the shops and public buildings becomes restricted due to badly designed access and layouts as well as lack of facilities such as toilets, nappy changing areas, lifts, and seating areas.

\section{Public realm and open space}

Design of public and semi-public areas, estates and open spaces do not incorporate the safety concerns of women (Cranz 1980). 


\section{Governance and decision making}

We also felt that the planners' lack of awareness on women' needs was one of the main reasons of insensitive design that women had to encounter every day. This also stemmed from the fact that women were mostly excluded from decision making processes.

\section{Women and planning - the role of the Town and Country Planning Summer School: the experience of Janice Morphet}

The introduction of the issue of women into discussion in mainstream planning came in 1983 through the decision of the annual Town and Country Planning School (TCPSS) to include an evening debate on the issue of women and planning in their planning officers' programme. The TCPSS had been founded in 1934 and established to provide a way for local authority councillors and senior officers to have an intensive updating and discussion of the current and future practices of planning. These events lasted over a week starting with a 4-day session for the councillors followed by a 7-day programme for chief planning officers. TCPSS were held in Universities to reinforce the educational character of their programme and to provide the opportunities for discussion, debate and, what would now be defined as, networking over meals and informal contact throughout the period of the school. The programme offered a menu that was always a mixture of set piece events by major planning or political speakers and supplemented by a range of more specialist seminars that were chosen from a programme offered to participants. Evening debates were more controversial raising emerging issues and were held after dinner in a more informal atmosphere.

The decision to hold an evening debate on women and planning at the 1983 St Andrews TCPSS was at the suggestion of one of the members of the TCPSS Council who were responsible for the management of the programme and the operation of the event. Early on, I was invited to deliver this session and to submit my own title. As a contribution to stimulating the debate, I had co-edited an edition of the Women and Planning newsletter in June 1982. I knew from the outset that this session would be challenging, not least as most of the senior officers in planning were men and that by the time the session was be held in the evening, they would be winding down from the day and have started drinking at dinner. My contribution was to start at 8.30 and be followed by a $q$ and a, after which everyone would move to the bar. 
My main consideration in preparing this talk was an awareness of the responsibility that I had in introducing this topic and that this would not lead to light-hearted session or antagonistic comments. This was an opportunity to raise the issues and it was important not to stimulate unhelpful comments or ridicule. I decided that the best approach would be to be very straightforward. Why would planning not address the issues of women in the environment and in the profession? I decided to call my talk 'Planning and the Majority - Women' basing this on the demographic data that showed that there were more women than men in the population and continued from there.

The atmosphere of the session was charged and there was a sense that it would be an 'event' - I was hoping it would be one that was remembered for the right reasons. I opened my presentation with the demographic facts and then briefly situated this in the relative roles and position of women in society. I then went on to outline some of the issues that needed to be recognised for women in the built environment including women's access to transport and multiple trips each day. I also discussed the issues of long-distance commuting (Little et al 1988) and its relationship to the location and type of employment available. Once having established some of the agenda that is of concern to women, I then continued to discuss what had been happening in London to start to address these issues including the programme of action supported by the GLC. I mentioned the review of the GLDP that was underway and the inclusion of women in the policy paper that was supporting this 'The Future of London' (GLC 1983). Finally, in this part of the talk I mentioned the Women and Planning conference at PCL in 1982 and the establishment of the RTPI working group on women in 1982. There were also other conferences on women and planning taking place after TCPSS in Liverpool (October 19823) and Edinburgh (November 1983).

In the next part of my talk, I went on to discuss the role of women in the planning profession. 1983 had been declared the year of positive action by the Equal Opportunities Commission and it was intended that this would address issues such as the role of women in local government who were on lower grades and pay - an issue that is still to be resolved today. I also suggested ways in which planning departments could support women having a career break when having children including maintaining links with them, inviting them to CPD events or designing specific CPD for women returners. Women could also be volunteers in Planning Aid. There was also a need for mainstream career development and training for women planners and councillors which was not provided specifically with this is mind. The talk was greeted in a more downbeat way than had been expected. The boisterous atmosphere had been managed and many of the participants seemed almost disappointed that there had not been the kind of showdown they were expecting. We all moved to the bar and I was pleased that I had been allowed to set out the issues in my own way. 
This approach at the 1983 TCPSS was followed by an invitation to offer three specialist seminars on 'Women and Planning' at the 1984 TCPSS in Edinburgh - in effect turning a topical issue into a mainstreamed one. In the 1984 programme these seminars were part of the full programme for practising planners attending the event and it was deemed to be popular enough to be able to offer it three times, so that a reasonable proportion of the TCPSS attendees could participate. These seminars marked the extent to which women and planning had moved from a controversial opportunity to discuss women and planning issues to a practice-based approach about what should be done. The proceedings of the TCPSS were always written up in an edition of 'The Planner', the RTPI membership journal and the report that I wrote on the seminars was published in the February 1985 edition that had with a cover of all white male participants at the event in Edinburgh (Morphet 1985).

The report of the seminars described them as an opportunity to consider the issues of women and planning in more detail than had been the case in the 1983 debate and without the more hostile climate reported at that event. The report shows that the seminars covered the same kind of ground as in 1983 but in more detail and extended consideration to issues such as public consultation, including the timing and location of meetings. Unlike the 1983 session, in 1984 men were also expressing their wish to be less pressurised at work and wanting to spend more time at home with their children.

After this, I attended conferences and events and later researched the role of women as local authority chief executives (Morphet 1990; 1992; 1993). I spoke at events and continued to write about the issue but the pressures of Thatcherism and the survival of planning as a whole in the late 1980s engulfed everything that was going on in the public sector including planning (Thornley 2018). The reemergence of the issue was through the Earth Summit in 1992 when the issues for women as part of sustainable development were clear through Local Agenda 21 planning (Morphet and Hams 1994) but by this time the issue of women had been considered mainstreamed.

\section{Women's Issues as special projects: Open Sesame the experience of Sule Takmaz Nisancioglu}

The work generated by the GLC was followed up by many local authorities in London. Local planning authorities in particular have carried out pioneering work in terms of encouraging women's involvement in plan-making, implementing some of the policies developed by the GLC and developing structures to tackle the work on women's issues. A number of boroughs set up women and planning working groups within their departments or employed women's issues officers specifically to work on 
gender planning. Southwark and Haringey were the first planning departments which established informal women and planning groups in 1983 to look at the implications of planning policies for women. Wandsworth became one of the first authorities to negotiate with developers for a shopper and workplace crèche in a major store in Clapham Junction and Haringey negotiated a crèche in a business centre in Tottenham (Takmaz-Nisancioglu 1990).

Against this background, as part of a service restructure, I was appointed as the Women's Issues Officer in Haringey Council Planning Policy department in 1988 to look for new ways of working and increasing women's participation in planning decision making process. The post created was at managerial level and I became a member of the service management team. The thinking behind this was to signal to the service and the community that the Planning Service wanted to achieve a significant change in this area, and this change was supported at managerial level.

I was supported by a service wide women's group which provided a framework for discussions on priorities within the department and by Women's Service Liaison Officers whose role was to bring to our attention staff related issues. We knew from our experiences and from the GLC work how planning policies and practice affect women's lives and how planning departments should be more representative of the population they serve. This was not a comprehensive list of concerns but was a good starting point. However, we wanted to know whether these concerns were also shared by local women. Also, women are not a uniform category, there are young women, old women, women from black and ethnic minorities, women with disabilities, women from different classes and their needs may differ.

So I started organising a programme of visits to hairdressers, GP clinics, nurseries, town centres, women's centres in the borough asking women what their concerns were. It was clear to me from the beginning that establishing a new role like mine, encouraging the service to take a critical look at itself, its policies and practices, and accessing resources for community engagement required a considerable management and political support, as well as support from women working in the service. Therefore, there were other female planners taking part in these community engagement meetings and events alongside me. The lead councillor for the Planning Committee also attended the meetings and chaired some of the discussions. Meetings were mainly in the form of informal exchange of ideas, concerns and challenges. Later in the project, there were questionnaires and surveys about specific activities such as the Open Sesame project mentioned below.

Many women we met indicated problems of accessibility in the borough's town centres from the point of view of women as carers including badly designed shop access and circulation areas, lack of facilities 
such as toilets, nappy changing areas, seating areas, that all made shopping trips problematic. The key message we received was that the location of shopping facilities and design of town centres are very important to women especially for those who don't have access to cars and are carers for children and with relatives with disabilities. Apart from finding out what local women thought about the cities we live in, these meetings also led to increase awareness of how planning were important to women's lives and the need to demystify our planning work.

\section{Open Sesame project}

Out of this initial work, came an idea of the Open Sesame project which was designed in discussions with local women who showed an interest in participating in events to raise awareness of accessibility issues. One group from the less affluent part of the borough, Northumberland Women and Children Centre, was particularly active in shaping the project. The project had the following aims:

a) to highlight the access problems of women as carers and to raise the awareness of planners and shop owners on this issue,

b) to encourage the business community to address the problems of access by way of awarding those shops which provide better access and basic facilities,

c) to develop ways of involving women living and working in Haringey in all aspects of environmental improvements and planning policy development.

The project group which included local women and planners organized two action days in Haringey's town centres where women with baby buggies, shopping bags or wheelchairs surveyed the accessibility of local shops. Amongst the findings, which were typical of other UK urban centres at the time

- Steep steps and narrow doors in most local shops and banks

- Low barriers and narrow turnstiles at supermarket entrances

- Lack of toilet facilities in most major chain stores

- Minimal signposting for existing good facilities

- Children's goods in basement or top floors of stores with no lifts.

(London Borough of Haringey, 1990) 
Following these surveys, Open Sesame invited male planners to experience the problem first-hand and asked them, including the head of service, to do similar surveys pushing baby-buggies and either sitting in or pushing wheelchairs in the borough's shopping areas. Believing that publicity is an important part of any project aimed at raising public awareness, the Open Sesame project group always invited the local and national press to their survey days out. Perhaps not surprisingly, the biggest interest shown by the press was for the male planners struggling up the steep steps and with the heavy doors with their baby buggies, as shown by ITV and BBC local TV news.

I also facilitated the process of developing good accessibility guidance based on the views of women participating in the projects and these were published and distributed to shops and stores. Local women were also invited to nominate least and most accessible shops for Open Sesame Awards. As planning and building control powers for accessibility, internal layout and facilities such as nappy changing areas were limited for existing shops, awards were designed to encourage the business community to improve their facilities. Access guidelines for town centres for use by planners in decision making process were also developed. As a way of monitoring, the project group also assessed planning decisions on the shop front accessibility and facilities. We found that accessibility gradually became one of the key considerations of planners when dealing with shop front applications (TakmazNisancioglu 1990). The project was widely reported in local, national and international platforms (OECD 1994; Takmaz-Nisancioglu and Greed C 1996).

With its emphasis on public participation and its aim of raising awareness on women's issues, Open Sesame contributed to our understanding of how to overcome the barriers to women's participation in the urban planning process and how planning policies must take into consideration the role and requirements of women. The project contributed to early discussions on sustainable development approaches by highlighting the importance of good quality local shopping facilities within walking distance of residential areas as opposed to out of town centres which are based on access by car.

Although it is not part of this current paper, it is still worth mentioning briefly that alongside service delivery and policy development projects like Open Sesame, the Planning Service also considered how to address inequalities in employment. One of the key achievements of this work led by Women's Service Liaison Officers, who had this as an additional role to their planning duties, was to get a management agreement to offer support, such as tuition fees and flexible working to those in the administrative section of the service, most of whom were women, if they wished to pursue a career in planning. 
Image 2- Open Sesame Leaflets and Questionnaire

\author{
Image 3-Open Sesame
}

\title{
What Happened Next?
}

The importance of these piece-meal but nevertheless innovative developments and actions by both the TCPSS and planning authorities helped to raise the issue of women and planning. Across London, these initiatives helped create space and resources for proactive, people-based and participatory approach to planning. However, the trend towards mainstreaming equalities as opposed to a special topic approach had been gathering pace in the 1990s, mainly as a response to local authorities under financial pressures from Central Government. By the mid- 1990s, many women's committees or women's issues posts in LPAs were abolished and absorbed into generic equalities posts in a central strategy or policy departments. One of the arguments for mainstreaming was that if women's issues are regarded as special topics, they will stay as such and will not become mainstream. By widening the responsibility to all, everybody will have to consider gender implications of their work and women's issues will become integral to local authority officers' thinking and decision-making processes.

However, Clara Greed (2003b) in her evaluation of gender mainstreaming, maintains that

"although generic equalities policy is widespread, it is primarily concerned with personnel matters and there is little understanding of the impact of gender considerations on planning policy. At best there is an assumption that only policies related to women's traditional roles are affected. At worst some LPAs do not consider gender to be of any relevance to the planning process, particularly in departments where there is little social awareness and a technical and quantitative approach predominates. Little will change unless central government gives highlevel guidance on mainstreaming, and resource allocation and awareness training are increased. Cultural change is needed within the profession to enable planners to take gender seriously" 


\section{Conclusions}

Although this paper does not advocate the re-establishment of a special women's issues' post as a solution to gender sensitive planning, it does highlight the need for resources for innovative work in local authority planning departments. This paper presents the experiences of women planners in English planning. The findings of the survey of British strategic planning agencies undertaken in the summer of 1998 (Reeves 2002) revealed particular gaps in understanding and knowledge and confirmed the complex nature of the barriers to implementing an approach to planning that considers the needs of women and men. The results demonstrated the limited capacity of strategic planning authorities to 'mainstream' gender issues into the principles, strategies and practices. The planning movement, comprising urban planners, geographers, architects and urban designers, have long been active trying to change spatial-policy and urban design (Greed, 1994a, 2003a; Roberts and Greed, 2001), but little implementation of alternative policies has been achieved (compare Little, 1994 with Little, 2002 and Little 2107). Gender mainstreaming has been welcomed by many adherents as the means of gaining recognition of women's 'different' spatial needs and reshaping planning policy. This assumption has proved mistaken. Whilst equalities mainstreaming is widespread within local government, much of the emphasis is upon generic approaches in which gender is given limited attention.

Work has continued to define and develop understanding of gender issues in planning. in 2001, Plymouth city council undertook a gender audit in panning, but it was not followed up (Greed, 2005) The RTPI published a gender mainstreaming toolkit (Reeves/WDS 2007) and the work of the Commonwealth Association of Planners was included in an OECD Commonwealth Secretariat Briefing Paper on Gender in Planning and Urban Development (Malaza 2009). This provided a range of illustrations about the ways in which these issues were being considered in different countries, including how to shift from awareness to practice. However, it concluded that many planners are still unaware of these issues, whether in general policy making or in the same specific practice issues that emerged in the 1970s including transport, safety and settlement design.

Capacity for reflection and proactive planning has eroded even further since the 1990s and under austerity conditions, as pointed out by the RTPI (2019) about their study on planners serving the public interest:

"Under-resourcing, coupled with reforms that have undermined planning's strategic role, have relegated it to a largely reactive, regulatory function in many local authorities, creating a "box- 
ticking culture that has closed off the space many planners traditionally used for reflection, professional discretion and proactive planning", according to the report. This makes it harder to undertake the long-term strategic thinking and professional discretion that both public and private sector planners feel is needed to deliver the public interest, the study says".

Are there any legacies that remain today? In terms of planning policies that recognise gender issues, then there is little evidence of any of this approach remains, although this special issue of TPR is a good opportunity to foreground the issues again. There are broader concerns for mobility within the public realm and within buildings but little on the specific needs of women in using space. For the role of women in the profession, then there has been more progress. There have been more women Presidents of the RTPI, since 1994 and the current and former Chief Executives are women. The chair of the RTPI board is also a woman. RTPI events have a policy of ensuring that there are women speakers on the platform. Informally, a legacy group of women who formed the core of the Women and Planning network in 1982 continued to meet on a regular basis, drawing in new women into WIMPs - Women in Management in Planning. However, this was overtaken by the creation of the Women in Planning network in 2012 and now has 14 branches across the UK and a network of over 1,000 . This has been set up outside the RTPI is providing networking, training, mentoring and support for younger women planners and it is likely that this will continue to grow and mature. This is needed not least as the number of women in leadership roles in the public and private sector remain small although women's membership of the RTPI is at 39\% (Kenny 2019) continues to grow. Is this a positive legacy from our experience in the decade we discuss here or an outcome of the changes in women's aspirations in society? We are not sure but are pleased that this progress is being made in the profession if not in planning policies.

\section{References}

Bagguley P., Mark-Lawson, J., Shapiro, D., Urry, J., Walby, S. and Warde, A. (1990) Restructuring: Place, Class and Gender. London: Sage.

Beebeejaun, Y. (2017). Gender, Planning, and Epistemic Injustice. Routledge.

Boddy, M., \& Fudge, C. (Eds.). (1984). Local socialism?: labour councils and new left alternatives. Macmillan International Higher Education.

Bowlby, S. (1984) Editorial. Built Environment (1978-), 10(1), 4-7.

Bowlby, S. (1990). Women, work and the family: control and constraints. Geography, 17-26. 
Boys, J. (1984). Is there a Feminist Analysis of Architecture? Built Environment, 10(1), 25-34.

Brindley, Tim, Yvonne Rydin, and Gerry Stoker. Remaking planning: The politics of urban change. Routledge, 2005.

Brown, C., Claydon, J., \& Nadin, V. (2003). The RTPI's education commission: Context and challenges. Town Planning Review, 74(3), 333-345.

Burns R. (1980) Women in Urban Management: breaking down the barriers. In Stimpson et all pp229234.

Cranz G. (1980). Women in urban parks in Stimpson et al pp 76-92.

David, M. (1978) Women caring for pre-school children in the USA. International Journal of Urban and Regional Research vol 2, 1-3, 440-462.

Dresser, M. (1978) review of Davidoff, L., L'Esperance, J., and Newby, H. 1976: Landscape with figures: home and community in English society. International Journal of Urban and regional Research. Vol 2, 1-3, 558-563.

Edwards, J. (1988). Local government women's committees. Local Government Studies, 14(4), 39-52.

Ferrier, M. (1976). Women, Post-Stretton. Royal Australian Planning Institute Journal, 14(3-4), 52-53.

Ferrier, M. (1977). Women and planning. Royal Australian Planning Institute Journal, 15(3), 101-101.

Floge, L. (1985). The dynamics of child-care use and some implications for women's employment. Journal of Marriage and the Family, 143-154.

Forrester, A., Lansley, S., \& Pauley, R. (1985). Beyond our ken: A guide to the battle for London. Fourth Estate.

Friedman, S. D., \& Greenhaus, J. H. (2000). Work and family--allies or enemies?: what happens when business professionals confront life choices. Oxford University Press, USA.

Greed, C. (1994). Women surveyors: constructing careers. Longman.

Greed, C. (1996). Promise or progress: women and planning. Built Environment, 22(1), 9-21.

Greed, C. H. (2003a). Women and planning: creating gendered realities. Routledge. 
Greed, C. (2003b). Gender mainstreaming within local planning authorities. In Proceedings of the Institution of Civil Engineers-Municipal Engineer (Vol. 156, No. 2, pp. 119-125). Thomas Telford Ltd.

Greed, C. (2005). An investigation of the effectiveness of gender mainstreaming as a means of integrating the needs of women and men into spatial planning in the United Kingdom. Progress in Planning, 64(4), 241-242.

Greed C. and Reeves D. (2003) Gender Equality and Plan making The gender mainstreaming Toolkit. London: RTPI .

Griffen C. (1980) Review of The American Woman in Transition: the urban influence 1870-1920. In Stimpson et al 266-268.

Hague, C. (2017). Challenging Institutions That Reproduce Planning Thought and Practice. Encounters in Planning Thought, 16, 222-241.

Halford, S. (1988). Women's initiatives in local government... where do they come from and where are they going?. Policy \& Politics, 16(4), 251-259. Hayden, D. (1982). The grand domestic revolution: A history of feminist designs for American homes, neighborhoods, and cities. mit Press.

Hayden, D., \& Wright, G. (1976). Architecture and urban planning. Signs: Journal of women in culture and society, 1(4), 923-933.

Hebbert, M. (1995). Unfinished Business: the remaking of London government, 1985-1995. Policy \& Politics, 23(4), 347-358.

Holcomb, B. (1984). Women in the Rebuilt Urban Environment: The United States Experience. Built Environment , 10(1), 18-24.

Huff, C. (2003). Towards a geography of women's life writing and imagined communities: An introductory essay. Prose Studies, 26(1-2), 1-16.

IBG (1984) Women, Geography Study Group of the IBG., \& Explorations in Feminism Collective (Great Britain). (1984). Geography and gender: an introduction to feminist geography. Random House of Canada Limited.

Jensen, M. (2009). Separated by a common language: the (differing) discourses of life writing in theory and practice. a/b: Auto/Biography Studies, 24(2), 299-314. 
Kenny, T. (2019) The UK Planning Profession in 2019. London: RTPI.

King, D. S. (1989). Political centralization and state interests in Britain: the 1986 abolition of the GLC and MCCs. Comparative Political Studies, 21(4), 467-494.

Lacey, N. (1987). Legislation against Sex Discrimination: Questions from a Female Perspective. JL \& Soc'y, $14,411$.

Leavitt, J. 1980. The History, Status and Concerns of Women Planners in Stimpson et al pp 223-227

Lewis, J., \& Foord, J. (1984). New Towns and New Gender Relations in Old Industrial Regions: Women's Employment in Peterlee and East Kilbride. Built Environment, 10(1), 42-52.

Little, J. (1994). Gender, planning, and the policy process (pp. Chapter-6). Oxford: Pergamon Press.

Little, J. (1999). Women, Planning, and Local Central Relations in the UK. Gender, Planning and Human Rights, London: Routledge, 25-38.

Little, J. (2017). Gender and rural geography. Routledge.

Little, J., Peake, L., \& Richardson, P. (Eds.). (1988). Women in cities: Gender and the urban environment. Macmillan International Higher Education.

London Borough of Haringey (1990) Results of the Open Sesame project, Report of Borough Planning Officer to Women's Committee. London: LB Haringey.

Lopata, H. Z. (1980). The Chicago women: A Study of patterns of mobility and transportation' in Stimpson et al pp 158-166.

Malaza, N. (2009), "Gender in Planning and Urban Development", Commonwealth Secretariat Discussion Paper, No. 7, Commonwealth Secretariat, London.

Markusen, A. (1980) 'City spatial structure, women's household work and national urban policy' in Stimpson et al pp 20-41.

Markusen A. and Hess, B. (1980) Older Women and the City in Stimpson et al pp 124-140.

Morphet, J. (1990). Women in local government: A case study. Public Money and Management, 10(1), 57-59. 
Morphet, J. (1992). Women local authority chief executives: roots and routes. Local Government Policy Making, 19, 3-3.

Morphet, J. (1993). The role of Chief Executives in local government. Harlow: Longman.

Morphet, J., \& Hams, T. (1994). Responding to Rio: a local authority approach. Journal of environmental planning and management, 37(4), 479-486.

OECD (2004) Women in the City: Housing, Services and the Urban Environment. High Level Conference proceedings 4-6 October. Paris: OECD.

O'Leary, B. (1987). Why was the GLC abolished?. International Journal of Urban and Regional Research, 11(2), 193-217.

Palmer, John. "Municipal enterprise and popular planning." New Left Review 159 (1986): 117.

Pickup, L. (1984). Women's Gender-Role and its Influence on Travel Behaviour. Built Environment, 10(1), 61-68.

Price, K. (1984). Women's Employment and Unemployment in the Current Recession: Facts or Ms Information? Built Environment, 10(1), 53-60.

Ravetz, A. (1984). The Home of Woman: A View from the Interior. Built Environment 10(1), 8-17.

Reeves, D. (2002). Mainstreaming gender equality: an examination of the gender sensitivity of strategic planning in Great Britain. Town Planning Review, 73(2), 197-214.

Reeves, D. and WDS (2007) Gender and Spatial Planning RTPI Good Practice Note no. 7. London: RTPI.

Roberts, M., \& Greed, C. (2014). Approaching urban design: the design process. Routledge.

Rose, H. (1978) In practice supported, in theory denied: an account of an invisible urban movement. International Journal of Urban and Regional Research. Vol 2, 1-3, 521-537.

RTPI (1996), Planning for Women (Practice Advice Note 12), London, RTPI. 
RTPI (2019) 'Serving the public interest? The reorganization of UK planning services in an age of reluctant outsourcing'. Study by RTPI and Newcastle University funded by ESRC; News Release by RTPI 30th January 2019 London.

Saegert, S. (1984) Masculine Cities and Feminized Suburbs: Contraditory Realities. In Stempson et al pp93-108

Stimpson, C. R., Dixler, E., Nelson, M. J. and Yatrakis, K. B. (1981). Women and the American city. University of Chicago Press.

Takmaz-Nisancioglu, S. (1990) MA Dissertation Women and Planning: Where do we go from here? . University of Westminster.

Takmaz-Nisancioglu, S.,Greed, C. (1996) Bringing down the barriers in living on the future: 24 Sustainable Development Ideas from the UK. London: UK National Council for Habitat II pp 16-17.

Thornley, A. (2018). Urban planning under Thatcherism: the challenge of the market. Routledge.

Travers, T. (1990). London after abolition. Local Government Studies, 16(3), 105-116.

Wagner, P. (1984). Suburban Landscapes for Nuclear Families: The Case of Greenbelt Towns in the United States. Built Environment, 10(1), 35-41.

Walshok, M. (1980) review of Women and the City special issue of International Journal of Urban and Regional Research. Vol 2, in Stimpson et al 268-270.

Weale, S. (1999) 'Beyond Red Ken' The Guardian 20 ${ }^{\text {th }}$ December https://www.theguardian.com/politics/1999/dec/20/londonmayor.uk

Wise V. (1985) GLC Women's Committee Women on the move GLC Survey on Women and Transport 3 Survey results safety harassment and violence. London: GLC.

Yogev, S. (1981). Do professional women have egalitarian marital relationships?. Journal of Marriage and the Family, 865-871. 